\title{
Intrauterine Treatment of Spina Bifida
}

\author{
${ }^{1}$ Luca Mazzone, ${ }^{2}$ Martin Meuli
}

\begin{abstract}
Prenatal repair for open spina bifida (OSB) represents nowadays a valid therapeutic option that must be considered whenever a fetus is diagnosed with this severe congenital malformation. However, a judicious weighing of the benefits obtained by fetal surgery against the risks is necessary for every individual case. This article provides the background information that is needed to accomplish that. It describes the evolution of fetal surgery for spina bifida, its benefits and risks, and the different techniques used today.
\end{abstract}

Keywords: Fetal surgery, Fetus, Intrauterine, In utero, Myelomeningocele, Myeloschisis, Prenatal repair, Spina bifida.

How to cite this article: Mazzone L, Meuli M. Intrauterine Treatment of Spina Bifida. Donald School J Ultrasound Obstet Gynecol 2017;11(4):347-354.

Source of support: Nil

Conflict of interest: None

\section{INTRODUCTION}

In March 2011, a groundbreaking article entitled “A randomized trial of prenatal vs postnatal repair of myelomeningocele" was published by Adzick et $\mathrm{al}^{1}$ in the New England Journal of Medicine. The article provided sound evidence of significant benefits obtained with prenatal repair of OSB. Since then, fetal repair of OSB has become increasingly a hot topic and centers offering fetal repair are starting to spread. While allowing all potential patients access to this innovative approach is indisputably the ultimate goal, an uncontrolled spreading bears the risk of jeopardizing the enterprise. Although the overall results of fetal repair are promising, they are far from being perfect and might additionally be shadowed by the inherent risks of the procedure. Only by understanding the important reservations regarding this innovative treatment, and concentrating these highly demanding and delicate cases in a few high-volume centers with proven expertise, patient safety can be maintained. This article reviews, therefore, not only the history and rationale of prenatal repair of OSB and the positive results obtained by the open approach,

\footnotetext{
${ }^{1}$ Consultant, ${ }^{2}$ Professor

1,2The Zurich Center for Fetal Diagnosis and Therapy, Zurich Switzerland; Department of Pediatric Surgery, University Children's Hospital, Zurich, Switzerland

Corresponding Author: Luca Mazzone, Consultant, The Zurich Center for Fetal Diagnosis and Therapy, Zurich, Switzerland Department of Pediatric Surgery, University Children's Hospital Zurich, Switzerland, e-mail: luca.mazzone@kispi.uzh.ch
}

but also its inherent problems, technical considerations, and the alternative endoscopic approach.

\section{Anatomy and Clinical Implications of OSB}

The OSB results from a failure of neurulation in early pregnancy (28 days of gestation). Two forms can be distinguished: Myelomeningocele (MMC; spina bifida cystica aperta) or myeloschisis (the noncystic variant). Along with non-neurulation of a part of the spinal cord, the vertebral arches and the soft tissue fail to close. In MMC, the non-neurulated spinal cord sits on top of a cystic sac formed dorsally by pia and ventrally by dura and the abnormally shaped arachnoidal space in between contains cerebrospinal fluid. In myeloschisis, the arachnoidal space and thus, the cyst are collapsed, and the non-neurulated spinal cord resides on the floor of the vertebral canal (Fig. 1). Importantly, in both variants, the neural tissue remains directly exposed to the amniotic fluid prenatally and to air postnatally. ${ }^{2}$

Beside the malformation at the back, a constellation of structural defects of the brain, cerebellum, and brain stem (subsumed as Chiari II malformation) are associated with OSB. Typical, but not the sole features of the Chiari II malformation are hydrocephalus, hindbrain herniation (a displacement of part of the brain stem and of the cerebellum through the foramen magnum in to the vertebral canal), and a small, "crowded," posterior fossa (Fig. 2).

Patients born with this severe congenital malformation suffer from a cluster of lifelong disabilities despite postnatal repair. The most important are paraparesis or paraplegia, neuropathic bladder and bowel dysfunction, and a shunt-dependent hydrocephalus. The former two are virtually always present, and hydrocephalus occurs in over $70 \%{ }^{3}$ Hindbrain herniation causes in up to $33 \%$ of patients operated postnatally, the dysfunction of cranial nerves, cerebellum, and medullary respiratory center. ${ }^{4-6}$ Corrective, rehabilitative, or palliative therapeutic measures are adopted to address the wide array of neurosurgical, neurologic, orthopedic, endocrinologic, sexual, and psychosocial issues that accompany the disabilities of OSB. A real cure, however, does not exist.

\section{Pathogenesis of OSB and the Rationale for Prenatal Repair}

For many years, the peripheral neurologic deficits seen in patients with OSB were thought to be the direct result of 


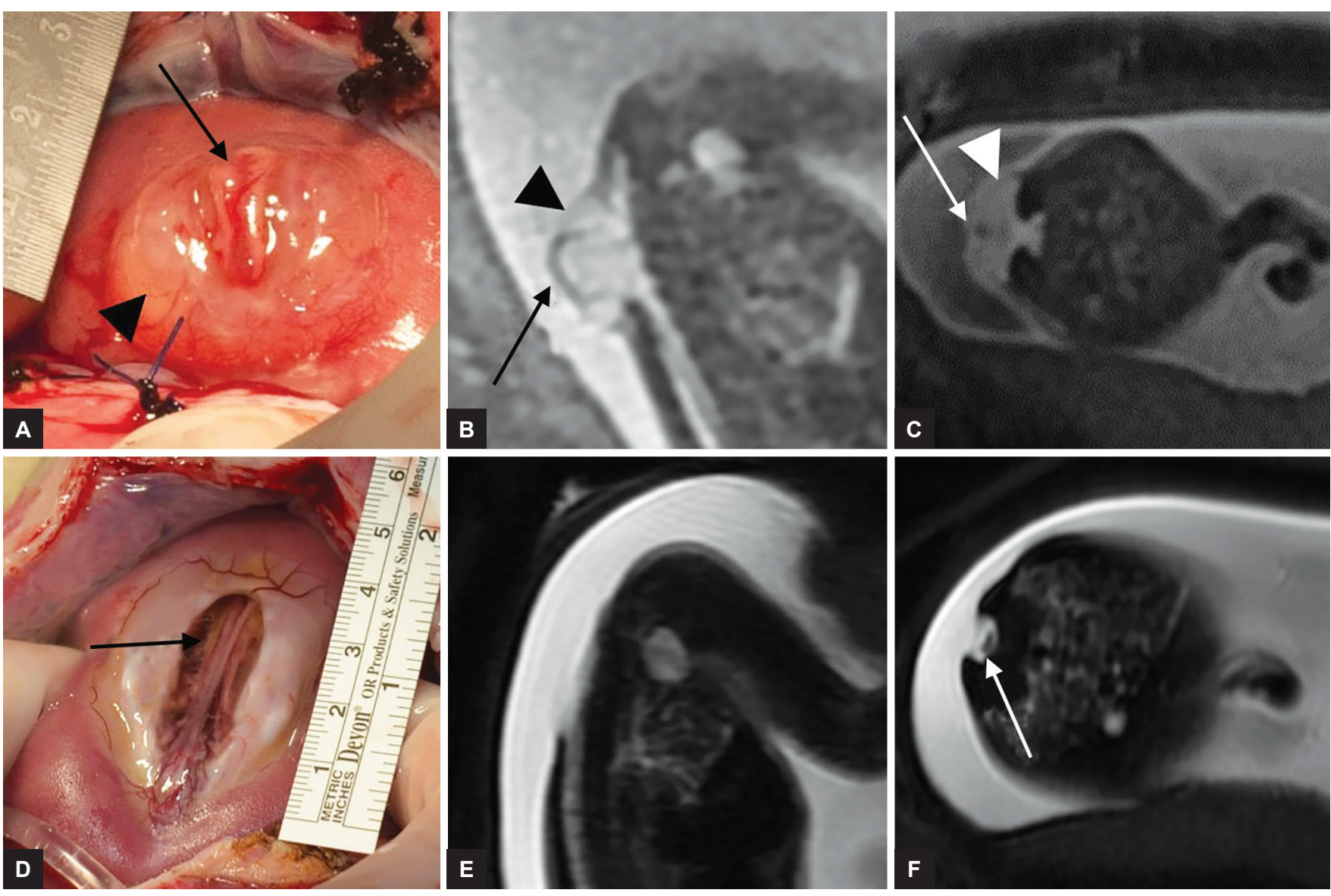

Figs 1A to F: Myelomeningocele: (A) Intraoperative image, preoperative fetal MRI; (B) sagittal view; (C) axial view. The non-neurulated placode (arrow) resides on the cystic sac (arrowhead). Myeloschisis: (D) intraoperative image, preoperative fetal MRI; (E) sagittal view; (F) axial view. There is no cystic sac. The non-neurulated placode sits on the floor of the vertebral canal (arrow)
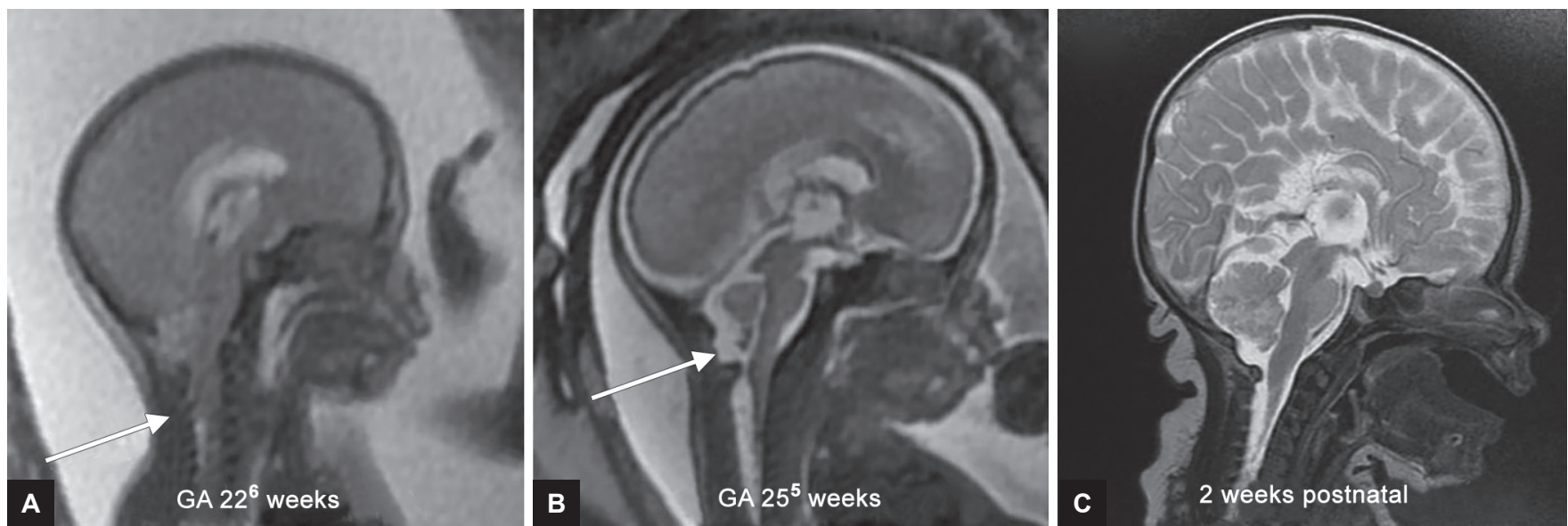

Figs 2A to C: (A) Preoperative fetal MRI: Hindbrain herniation (cerebellar herniation down to C3) and small "crowded" posterior fossa (arrow). (B) Three weeks after fetal spina bifida repair: Hindbrain herniation has already resolved, cerebrospinal fluid is detectable in the posterior fossa (arrow). (C) Postnatal MRI: No herniation of cerebellum or brain stem. Basal cistern with normal width

the non-neurulation. With the advent of fetal surgery at the end of the last century, attention was directed to the prenatal history of congenital malformation. It became clear that in some malformations, the evolution during gestation could be affected by negative processes that would eventually become clinically relevant at birth. Following that spirit, the prenatal natural history of spina bifida was studied extensively in the 1990s. Analysis of the spina bifida lesions of aborted fetuses ${ }^{7-9}$ demonstrated that although the spinal cord tissue within the lesion was always non-neurulated, the microstructure of the cord as well as the sensorimotor projections were regularly present. However, the more advanced the gestation was, the more damage, such as abrasion, erosion, disruption, 
hemorrhage, inflammation, and degeneration of the neural tissue was found, in some specimens up to complete disappearance. ${ }^{2}$ These observations led to the "twohit-hypothesis": A first hit being the non-neurulation and a second hit an in utero acquired spinal cord destruction by the direct and prolonged exposure to the amniotic fluid. Consequently, the enthralling idea came up that timely in utero coverage could protect the spinal cord and stop the otherwise progressing destruction.

Persuasive proof of the two-hit hypothesis was achieved experimentally with different animal models. ${ }^{9-15}$ It was possible to mimic the in utero progressive damage to the normal spinal cord by exposing it to amniotic fluid, and it was demonstrated that in utero coverage of the spinal cord could hinder damage and thus spare function. Additionally, the animal experiments showed also that by creating a spina bifida-like lesion and thus, a cerebrospinal fluid leak, a hindbrain herniation could be provoked. Not only sealing the leak by in utero repair reversed this experimentally induced "Chiari malformation". ${ }^{16,17}$ but the evidence obtained by all these experiments paved the way for fetal OSB repair to be commenced in human fetuses.

\section{Results of Prenatal Repair}

In 1997, Bruner et $\mathrm{al}^{18}$ from Vanderbilt University reported on the very first case of a endoscopic human fetal MMC repair. In 1998, two groups [Tulipan from Vanderbilt University $^{19}$ and Adzick et $\mathrm{al}^{20}$ from the Children's Hospital of Philadelphia (CHOP)] reported independently the first cases of successful open in utero repair. Both groups published a year later sister publications in the same JAMA issue: They reported that fetal OSB repair reversed hindbrain herniation in a majority of fetuses and reduced the need for ventriculoperitoneal shunting by about $50 \%{ }^{21,22}$ Several follow-up studies by both groups confirmed the reversibility of hindbrain herniation (Fig. 2) and the dropping of shunt rate. ${ }^{23-26}$ Moreover, favorable evolution with regard to head size, ${ }^{27}$ brain stem function, ${ }^{28}$ motor function of the legs, ${ }^{29}$ and different neurodevelopment parameters could be observed. ${ }^{30,31}$ However, bladder dysfunction, one of the major problems of OSB, seemed not to improve after prenatal repair. ${ }^{32-34}$ Another downside was that some patients had worsening neurology due to tethering of the spinal cord at the repair site. ${ }^{35}$ Further, prenatal OSB repair was associated with increased maternal risks (including preterm labor and uterine dehiscence), risk of premature birth, and increased risk of fetal or neonatal death. ${ }^{22,25}$ Despite the maternal risks at the time of prenatal OSB repair, the $\mathrm{CHOP}$ group could show that reproductive capacity was not lost after prenatal OSB repair and that the hysterotomy risks ware comparable to patients with classical cesarean section. ${ }^{36}$
These clinical data with all the above-described positive and negative aspects prompted the conception of a prospective, multicenter, randomized controlled trial to compare safety and efficacy of prenatal os postnatal OSB repair (Management of Myelomeningocele Study, MOMS trial). ${ }^{1}$

The MOMS trial began in 2003 and took 7 years. It was stopped prematurely after inclusion of 183 of the planned 200 cases based on the efficacy of the prenatal group. The prenatal group did significantly better with regard to hindbrain herniation (no herniation: Prenatal/ postnatal $=36 \% / 4 \%, \mathrm{p}<0.001$, severe herniation $=$ prenatal/postnatal: $6 \% / 22 \%, \mathrm{p}<0.001)$, shunt placement at the age of 12 months (prenatal/postnatal $=40 \% / 82 \%$, $\mathrm{p}<0.001)$, a composite score derived from the Bayley Mental Development Index and the difference between the functional and the anatomical levels of the lesion at 30 months ( $p=0.007)$, and, finally, regarding independent walking at 30 months (prenatal/postnatal: $42 \% / 21 \%$, p < 0.01). Yet, prenatal surgery was associated with an increased risk of preterm delivery and uterine dehiscence at delivery. In detail, oligohydramnios (prenatal/postnatal 21\%/4\%), spontaneous rupture of membranes $(46 \% / 8 \%)$, spontaneous labor $(38 \% / 14 \%)$, and preterm delivery (79\%/15\%, average ages 34.1 vs 37.3 weeks) were significantly more frequent in the prenatal than in the postnatal group $(\mathrm{p}<0.001)$. Although maternal safety was preserved, the hysterotomy site was found thinned in $25 \%$ of the mothers and dehiscent in $10 \%$.

In summary, the trial demonstrated unequivocally that prenatal OSB repair is not completely curative and that risks are associated with it, but also that it definitely yields the best overall results achievable today.

After the MOMS trial, centers offering prenatal OSB repair (among them our Zurich Center for Fetal Diagnosis and Therapy with over 60 cases, data to be published soon) showed that the MOMS-trial results can also be reproduced outside the setting of a rigorous trial. ${ }^{37-40}$ and additional studies looked at different aspects of prenatal OSB repair. The data from the MOMS trial were further analyzed in substudies. One study focused on the need for shunt placement ${ }^{41}$ after prenatal OSB repair. It demonstrated that the ventricle size at initial screening is an important predictor. In the prenatal group, $20 \%$ of those with ventricle $<10 \mathrm{~mm}, 45.2 \%$ with ventricle size of 10 to $15 \mathrm{~mm}$, and $79 \%$ with ventricle size $\geq 15 \mathrm{~mm}$ received a shunt. In the postnatal group, percentages were $79.4,86.0$, and $87.5 \%$ respectively ( $p=0.02$ ). Thus, patients that have a ventricle size at screening over $15 \mathrm{~mm}$ do not have a benefit from fetal repair regarding hydrocephalus. Another study analyzed the effect of prenatal repair on bladder function. ${ }^{42}$ Although prenatal 
OSB repair did not significantly reduce the need for clean intermittent catheterization at 30 months; it was shown that patients had less bladder wall trabeculation and less open bladder neck. As the author stated, the implication of these findings are unclear at this point. In the same year, $\mathrm{Carr}^{43}$ published a 5-year follow-up of 54 patients operated at $\mathrm{CHOP}$ before the MOMS trial. This group demonstrated a greater likelihood to successfully toilet-train than historical controls. In this respect, our own data published a year later by Horst et $\mathrm{al}^{44}$ suggest a positive effect of prenatal MMC closure on lower urinary tract function. However, several other studies, some of them with a weak study design, were not able to demonstrate improved urological outcome after OSB repair. ${ }^{45-47}$ Hence, further (prospective) data are needed and hopefully, the follow-up study of the MOMS trial patients at school age will provide a clearer view of the urological outcome after prenatal OSB.

Obstetrical outcomes and risk factors for obstetrical complications were analyzed in a third substudy. ${ }^{48}$ The article updated and expanded the information presented in the original MOMS report. Finally, the long-term impact and parental stress on the families of the women who participated in the MOMS trial were assessed. ${ }^{49}$ Families of women who had prenatal repair had a significantly lower overall negative impact of caring for a child with spina bifida up to 30 months of age when compared with those that had postnatal repair.

\section{Diagnostic Workup and Eligibility for Prenatal OSB Repair}

Details on detection of spina bifida by ultrasound is a topic of its own and beyond this review article. However, ultrasound is not only crucial to diagnose the presence of a spina bifida, it also should provide information on the kind of spinal dysraphism (open or closed), on the functional level of the lower extremity, and on whether additional anomalies concerning the fetus or the placenta/uterus might be present that would preclude fetal repair. The sonographic appearance of the lesion itself may not always allow a distinction of the type of spinal dysraphism; however, presence or absence of hindbrain herniation can be used as an indirect indicator. In fact, in closed spinal dysraphism, such as meningocele, lipomyelocele, and myelocystocele, the Chiari II malformation is not typically present. Although presence or absence of Chiari II can be assessed with ultrasound, fetal magnetic resonance imaging (MRI) allows to best visualize it and is thus an absolutely necessary tool in the workup for prenatal OSB repair. ${ }^{50,51}$ Figure 3 depicts a case with a closed dysraphism (meningocele) and absence of Chiari II.

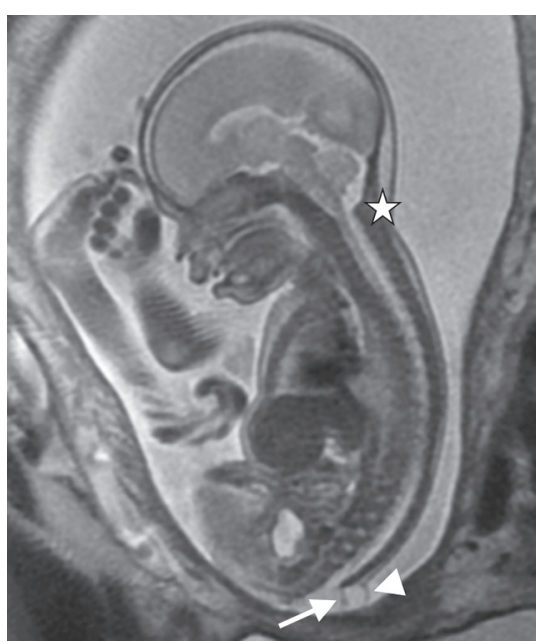

Fig. 3: A fetus with a meningocele (closed dysraphism) and, therefore, not eligible for fetal spina bifida repair. There is no hindbrain herniation (asterisk). The lesion (arrowhead) could be misinterpreted as myelomeningocele. The thin skin coverage is not always clearly distinguishable. The thickened filum terminale (arrow) could be misjudged as protrusion of a placode

Both dynamic MRI sequences and ultrasound are useful to assess the functional level of the lower extremities and are thus central for counseling. With ultrasound, Carreras et $\mathrm{al}^{52}$ demonstrated in patients with prenatal OSB an agreement of over $88 \%$ between prenatal and postnatal segmental levels. Hence, the functional level at the time of screening is helpful to give an individualized prognosis in regard of future lower extremity function.

For the MOMS trial, several exclusion criteria were defined. Some of them represented clear contraindications to fetal surgery; others were specifically formulated for the trial to minimize confounding variables. Although most centers performing prenatal repair employ the majority of the criteria set in the MOMS trial (Table 1), some criteria have been discarded and others have been revised. ${ }^{53}$ Generally speaking, for a patient to qualify for fetal surgery, the mother must be healthy and the fetus must not suffer from other pathologies than the spina bifida complex. Figure 4 shows an example of a fetus not eligible for fetal surgery due to a severe kyphosis and a suspected caudal regression syndrome. Further, prenatal OSB should be performed between 23.0 and 25.9 weeks of gestation. In the MOMS trial, the window for prenatal OSB repair was set between 19.0 and 25.9 gestational weeks. Study results from before the MOMS trial had shown that repair after 26 weeks would no longer yield a substantial benefit. ${ }^{25} \mathrm{~A}$ study from $\mathrm{CHOP}$ that was published after the MOMS trial demonstrated that repair before 23 weeks is associated with higher rates of preterm premature rupture of membranes and chorioamniotic membrane separation; ${ }^{54}$ it is, therefore, not any longer recommended to offer prenatal OSB repair before 23 weeks. 
Table 1: The MOMS trial eligibility criteria for prenatal OSB repair

Fetal

OSB at level T1-S1

Hindbrain herniation confirmed by MRI

No kyphosis in the fetus of $30^{\circ}$ or more

No fetal anomalies that are not related to spina bifida

Normal karyotype or fluorescence in situ hybridization

Maternal

Age older than 18 years

$19^{0}-25^{6}$

Singleton pregnancy

$\mathrm{BMI}<35$

No short cervix $(<20 \mathrm{~mm})$

No current or planned cerclage, no history of incompetent cervix No previous spontaneous singleton delivery prior to 37 weeks No placenta previa or placental abruption

No uterine anomaly, such as large or multiple fibroids or Mullerian duct abnormality

No previous hysterotomy in the active segment of the uterus (whether from a previous classical cesarean, uterine anomaly, such as an arcuate or bicornuate uterus, major myomectomy resection, or previous fetal surgery)

No insulin-dependent pregestational diabetes

No maternal-fetal Rh isoimmunization, Kell sensitization, or a history of neonatal alloimmune thrombocytopenia

Negative human immunodeficiency virus and hepatitis $B$ results, no history of hepatitis $C$ positivity

No other maternal medical condition, which is a contraindication to surgery or general anesthesia

No maternal hypertension, which would increase the risk of preeclampsia or preterm delivery (including, but not limited to: uncontrolled hypertension, chronic hypertension with end organ damage and new-onset hypertension in current pregnancy)

\section{The Open Repair}

The open approach, with the MOMS trial proven efficacy, is nowadays the gold standard for prenatal OSB repair. Here, we provide a short description of the procedure, although it simplifies enormously an operation, i.e., similar to a symphony, highly complex and only successful if orchestrated precisely and performed by adequately trained specialists. The procedure is done under general anesthesia and full uterine relaxation, typically obtained by a volative anesthetic agent. Access to the uterus is obtained by a transverse laparotomy. The border of the placenta is mapped with sterile ultrasound on the uterus and the hysterotomy is planned in a safe distance from it. Before entering the uterus, it is essential that the fetus is positioned in order to have the back in the designated area of the hysterotomy. The hysterotomy is usually performed with a stapler that places absorbable copolymer staples. The stapler has the advantage of compressing the uterine wall, thus impeding bleeding, and to avoid separation of the membranes by fixating them at hysterotomy border. During the whole procedure, the fetal heart rate and myocardial contractility are monitored with ultrasound. The uterine cavity is irrigated with warmed Ringer's solution throughout the procedure.

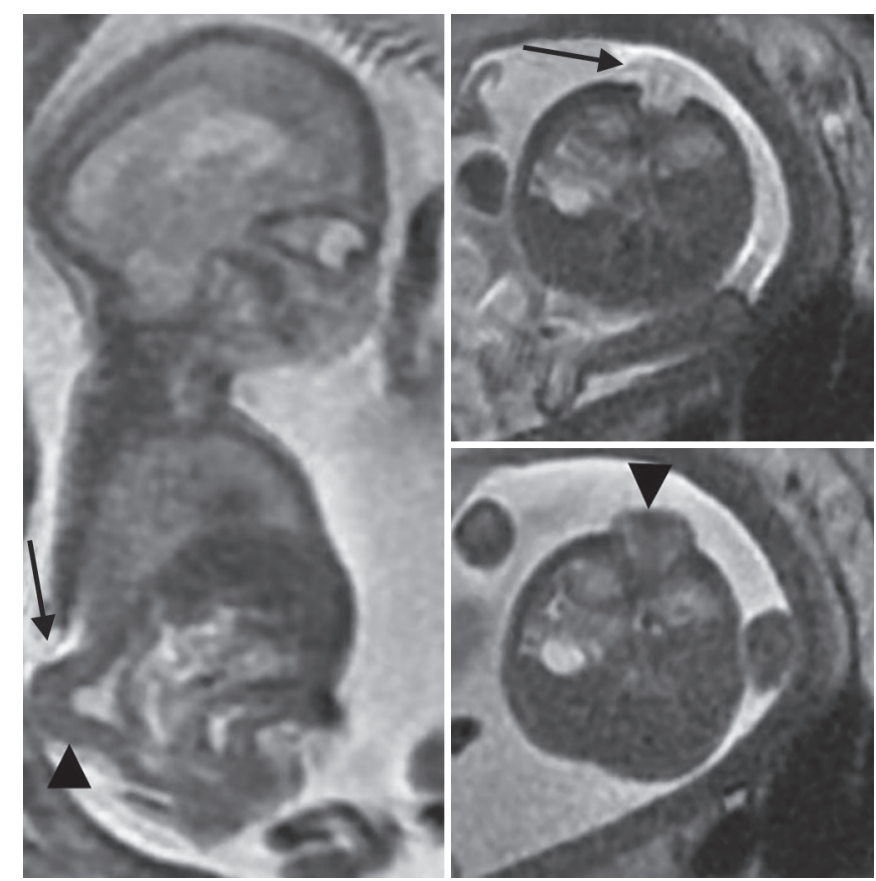

Fig. 4: A fetus with a myelomeningocele (arrow) and a suspected caudal regression syndrome with massive kyphosis (arrowhead). The patient is not eligible for fetal repair

The back of the fetus is centered in the hysterotomy wound and the lesion is repaired in the same technique as used postnatally: The zona epithelioserosa is resected, the dura is closed watertight and reinforced by paraspinal (myo) fascial flaps, and finally the skin is closed. In some cases, and, especially in myeloschisis, large skin defects may not allow a primary skin closure and avital dermal skin substitutes $^{55}$ can be used to close the skin gap. Rotation flaps, as used by our group, offer in these situations the advantage to have normal skin over the repair site. ${ }^{56}$ After completion of the fetal repair, the uterus is closed in two layers and the amniotic fluid is replaced by Ringer's solution. Finally, the laparotomy is closed in layers.

The learning curve of the procedure and the subsequent refinements of operative technique and perioperative management have led to better results and less complications than originally reported in the MOMS trial. ${ }^{37,38,57,58}$ For instance, in our own current experience of 65 cases, we had only one patient with mild pulmonary edema (1.5\%, MOMS 6\%) and no patient requiring transfusion at delivery (MOMS 9\%). Further, in our cohort, a higher rate of complete resolution of hindbrain herniation (over 90\%) ${ }^{59}$ (MOMS 36\%), and a higher median gestational age at birth have been noted. ${ }^{60}$ In addition, a different tocolysis management has led to markedly less side effects without compromising uterine efficacy. ${ }^{60}$

Despite all these improvements, the procedure remains a great challenge and, especially, the hysterotomy remains a critical risk factor. A cesarean section before onset of labor is obligatory to avoid intralabor uterine rupture. 


\section{The Fetoscopic Repair}

The maternal morbidity of open fetal repair prompted several groups in the world to endeavor to a minimal invasive approach. ${ }^{52,61-66}$ While the fetoscopic approach might look at a first sight like an attractive alternative to open surgery (and will hopefully be the method of choice in the future), several unresolved problems do still hold back the procedure to become the gold standard. Although maternal morbidity is clearly decreased by the fetoscopic approach, the fetus is exposed to a significant higher risk of prematurity and to a questionable efficacy of the repair.

Different endoscopic repair techniques have been proposed. The access to the uterus might be achieved by a percutaneous approach or by exposing directly the uterus through a laparotomy as done in open repair. The truly minimal invasive percutaneous approach has important limitations: Port site (membrane) control, positioning, and holding the fetus are impossible or at best extremely challenging, and an anterior placenta may not allow access to the fetus at all. Heavy problems, such as fetal demise, strong trocar site bleeding that required termination of an uncompleted operation, incomplete or even failed patch coverage, oligohydramnios due to port site leaks, premature rupture of membranes, chorioamnionitis, and prematurity as low as 28 weeks have been encountered by groups using the percutaneous approach. ${ }^{67-69}$ On the contrary, the technique where the uterus is exposed by a laparotomy allows port site control, a noninvasive positioning and fixation of the fetus, and a safe access also in patients with anterior placenta. ${ }^{63}$ While in open fetal OSB surgery, the repair is done as postnatally with a three-layer closure (see earlier), the fetoscopic approach adopts simply patches or a direct skin closure. The patch coverage of the lesion might in the best case scenario exert a protective effect on the exposed spinal cord tissue and hinder leakage of cerebrospinal fluid; however, a nonwatertight closure with the patch technique is frequent and several patients have required postnatal neurosurgical repair. How well a patch or a simple skin closure over the exposed non-neurulated spinal cord is protective is not known. In addition, there is a debate whether uterine carbon dioxide insufflation might be harmful to the fetus. ${ }^{70}$ In summary, although the endoscopic approach seems to reduce the bystander risk-i.e., the maternal risk, it also seems to do it on the cost of the actual patient-i.e., the fetus with spina bifida. Until it cannot be demonstrated (ideally by a randomized trial) that outcomes after fetoscopic repair are at least as good or even better than after open repair, the standard technique should remain the open approach.

\section{CONCLUSION}

The overall positive results from numerous studies make today prenatal OSB repair a valid therapeutic option that needs to be offered to parents when OSB is diagnosed prenatally. However, it must be stressed that prenatal repair is not a complete cure, is not free of risks for mother and fetus, and that it is unknown whether it produces longlasting benefits. Due to these reservations and bearing in mind the relative rare incidence of spina bifida, all efforts should be made to concentrate the highly demanding procedure to a few truly qualified high-volume centers worldwide. Dilution of cases because of too many centers will undisputedly put patient safety and the potential positive outcome of the procedure at risk. In view of this, a position paper by the "MMC Maternal-Fetal Management Task Force" published in the American Journal of Obstetrics and Gynecology ${ }^{71}$ has proposed optimal practice criteria that should be adopted and fulfiled for a center to offer prenatal OSB repair. Although the proposed criteria are not intended to be for legal or regulatory purposes, we strongly advise to comply with it.

\section{REFERENCES}

1. Adzick NS, Thom EA, Spong CY, Brock JW 3rd, Burrows PK, Johnson MP, Howell LJ, Farrell JA, Dabrowiak ME, Sutton LN, et al. A randomized trial of prenatal versus postnatal repair of myelomeningocele. N EnglJ Med 2011 Mar 17;364(11):993-1004.

2. Meuli M, Moehrlen U. Fetal surgery for myelomeningocele: a critical appraisal. Eur J Pediatr Surg 2013 Apr;23(2):103-109.

3. Copp AJ, Adzick NS, Chitty LS, Fletcher JM, Holmbeck GN, Shaw GM. Spina bifida. Nat Rev Dis Primers 2015 Apr 30;1:15007.

4. McLone DG, Dias MS. The Chiari II malformation: cause and impact. Childs Nerv Syst 2003 Aug;19(7-8):540-550.

5. Mitchell LE, Adzick NS, Melchionne J, Pasquariello PS, Sutton LN, Whitehead AS. Spina bifida. Lancet 2004 Nov 20-26;364(9448):1885-1895.

6. Just M, Schwarz M, Ludwig B, Ermert J, Thelen M. Cerebral and spinal MR-findings in patients with postrepair myelomeningocele. Pediatr Radiol 1990;20(4):262-266.

7. Hutchins GM, Meuli M, Meuli-Simmen C, Jordan MA, Heffez DS, Blakemore KJ. Acquired spinal cord injury in human fetuses with myelomeningocele. Pediatr Pathol Lab Med 1996 Sep-Oct;16(5):701-712.

8. Meuli M, Meuli-Simmen C, Hutchins GM, Seller MJ, Harrison MR, Adzick NS. The spinal cord lesion in human fetuses with myelomeningocele: implications for fetal surgery. J Pediatr Surg 1997 Mar;32(3):448-452.

9. Heffez DS, Aryanpur J, Hutchins GM, Freeman JM. The paralysis associated with myelomeningocele: clinical and experimental data implicating a preventable spinal cord injury. Neurosurgery 1990 Jun;26(6):987-992.

10. Michejda M. Intrauterine treatment of spina bifida: primate model. Z Kinderchir 1984 Aug;39(4):259-261.

11. Heffez DS, Aryanpur J, Rotellini NA, Hutchins GM, Freeman JM. Intrauterine repair of experimental surgically created dysraphism. Neurosurgery 1993 Jun;32(6):1005-1010.

12. Housley HT, Graf JL, Lipshultz GS, Calvano CJ, Harrison MR, Farmer DL, Jennings RW. Creation of myelomeningocele in the fetal rabbit. Fetal Diagn Ther 2000 Sep-Oct;15(5):275-279.

13. Meuli M, Meuli-Simmen C, Hutchins GM, Yingling CD, Hoffman KM, Harrison MR, Adzick NS. In utero surgery 
rescues neurological function at birth in sheep with spina bifida. Nat Med 1995 Apr;1(4):342-347.

14. Meuli M, Meuli-Simmen C, Yingling CD, Hutchins GM, Hoffman KM, Harrison MR, Adzick NS. Creation of myelomeningocele in utero: a model of functional damage from spinal cord exposure in fetal sheep. J Pediatr Surg 1995 Jul;30(7):10281032; discussion 1032-1033.

15. Meuli M, Meuli-Simmen C, Yingling CD, Hutchins GM, Timmel GB, Harrison MR, Adzick NS. In utero repair of experimental myelomeningocele saves neurological function at birth. J Pediatr Surg 1996 Mar;31(3):397-402.

16. Bouchard S, Davey MG, Rintoul NE, Walsh DS, Rorke LB, Adzick NS. Correction of hindbrain herniation and anatomy of the vermis after in utero repair of myelomeningocele in sheep. J Pediatr Surg 2003 Mar;38(3):451-458; discussion 451-458.

17. Paek BW, Farmer DL, Wilkinson CC, Albanese CT, Peacock W, Harrison MR, Jennings RW. Hindbrain herniation develops in surgically created myelomeningocele but is absent after repair in fetal lambs. Am J Obstet Gynecol 2000 Nov;183(5):1119-1123.

18. Bruner JP, Tulipan NE, Richards WO. Endoscopic coverage of fetal open myelomeningocele in utero. Am J Obstet Gynecol 1997 Jan;176(1 Pt 1):256-257.

19. Tulipan N, Bruner JP. Myelomeningocele repair in utero: a report of three cases. Pediatr Neurosurg 1998 Apr;28(4):177-180.

20. Adzick NS, Sutton LN, Crombleholme TM, Flake AW. Successful fetal surgery for spina bifida. Lancet 1998 Nov 21;352(9141):1675-1676.

21. Bruner JP, Tulipan N, Paschall RL, Boehm FH, Walsh WF, Silva SR, Hernanz-Schulman M, Lowe LH, Reed GW. Fetal surgery for myelomeningocele and the incidence of shunt-dependent hydrocephalus. JAMA 1999 Nov 17;282(19):1819-1825.

22. Sutton LN, Adzick NS, Bilaniuk LT, Johnson MP, Crombleholme TM, Flake AW. Improvement in hindbrain herniation demonstrated by serial fetal magnetic resonance imaging following fetal surgery for myelomeningocele. JAMA 1999 Nov 17;282(19):1826-1831.

23. Tulipan N, Hernanz-Schulman M, Lowe LH, Bruner JP. Intrauterine myelomeningocele repair reverses preexisting hindbrain herniation. Pediatr Neurosurg 1999 Sep;31(3): 137-142.

24. Johnson MP, Sutton LN, Rintoul N, Crombleholme TM, Flake AW, Howell LJ, Hedrick HL, Wilson RD, Adzick NS. Fetal myelomeningocele repair: short-term clinical outcomes. Am J Obstet Gynecol 2003 Aug;189(2):482-487.

25. Tulipan N, Bruner JP, Hernanz-Schulman M, Lowe LH, Walsh WF, Nickolaus D, Oakes WJ. Effect of intrauterine myelomeningocele repair on central nervous system structure and function. Pediatr Neurosurg 1999 Oct;31(4):183-188.

26. Bruner JP, Tulipan N, Reed G, Davis GH, Bennett K, Luker KS, Dabrowiak ME. Intrauterine repair of spina bifida: preoperative predictors of shunt-dependent hydrocephalus. Am J Obstet Gynecol 2004 May;190(5):1305-1312.

27. Danzer E, Johnson MP, Wilson RD, Flake AW, Hedrick HL, Sutton LN, Adzick NS. Fetal head biometry following in-utero repair of myelomeningocele. Ultrasound Obstet Gynecol 2004 Nov;24(6):606-611.

28. Danzer E, Finkel RS, Rintoul NE, Bebbington MW, Schwartz ES, Zarnow DM, Adzick NS, Johnson MP. Reversal of hindbrain herniation after maternal-fetal surgery for myelomeningocele subsequently impacts on brain stem function. Neuropediatrics 2008 Dec;39(6):359-362.
29. Danzer E, Gerdes M, Bebbington MW, Sutton LN, Melchionni J, Adzick NS, Wilson RD, Johnson MP. Lower extremity neuromotor function and short-term ambulatory potential following in utero myelomeningocele surgery. Fetal Diagn Ther 2009;25(1):47-53.

30. Danzer E, Gerdes M, Bebbington MW, Zarnow DM, Adzick NS, Johnson MP. Preschool neurodevelopmental outcome of children following fetal myelomeningocele closure. Am J Obstet Gynecol 2010 May;202(5):450.e1-450.e9.

31. Johnson MP, Gerdes M, Rintoul N, Pasquariello P, Melchionni J, Sutton LN, Adzick NS. Maternal-fetal surgery for myelomeningocele: neurodevelopmental outcomes at 2 years of age. Am J Obstet Gynecol 2006 Apr;194(4):1145-1150; discussion 1150-1152.

32. Holzbeierlein J, Pope JC IV, Adams MC, Bruner J, Tulipan N, Brock JW 3rd. The urodynamic profile of myelodysplasia in childhood with spinal closure during gestation. J Urol 2000 Oct;164(4):1336-1339.

33. Holmes NM, Nguyen HT, Harrison MR, Farmer DL, Baskin LS. Fetal intervention for myelomeningocele: effect on postnatal bladder function. J Urol 2001 Dec;166(6):2383-2386.

34. Koh CJ, DeFilippo RE, Borer JG, Khoshbin S, Bauer SB. Bladder and external urethral sphincter function after prenatal closure of myelomeningocele. J Urol 2006 Nov;176(5):2232-2236.

35. Danzer E, Adzick NS, Rintoul NE, Zarnow DM, Schwartz ES, Melchionni J, Ernst LM, Flake AW, Sutton LN, Johnson MP. Intradural inclusion cysts following in utero closure of myelomeningocele: clinical implications and follow-up findings. J Neurosurg Pediatr 2008 Dec;2(6):406-413.

36. Wilson RD, Lemerand K, Johnson MP, Flake AW, Bebbington M, Hedrick HL, Adzick NS. Reproductive outcomes in subsequent pregnancies after a pregnancy complicated by open maternal-fetal surgery (1996-2007). Am J Obstet Gynecol 2010 Sep;203(3):209.e1-209.e6.

37. Moldenhauer JS, Soni S, Rintoul NE, Spinner SS, Khalek N, Martinez-Poyer J, Flake AW, Hedrick HL, Peranteau WH, Rendon N, et al. Fetal myelomeningocele repair: the postMOMS experience at the Children's Hospital of Philadelphia. Fetal Diagn Ther 2015;37(3):235-240.

38. Botelho RD, Imada V, Rodrigues da Costa KJ, Watanabe LC, Rossi Júnior R, De Salles AAF, Romano E, Peralta CF. Fetal myelomeningocele repair through a mini-hysterotomy. Fetal Diagn Ther 2017;42(1):28-34.

39. Cavalheiro S, da Costa MD, Moron AF, Leonard J. Comparison of prenatal and postnatal management of patients with myelomeningocele. Neurosurg Clin N Am 2017 Jul;28(3): 439-448.

40. Elbabaa SK, Gildehaus AM, Pierson MJ, Albers JA, Vlastos EJ. First 60 fetal in-utero myelomeningocele repairs at Saint Louis Fetal Care Institute in the post-MOMS trial era: hydrocephalus treatment outcomes (endoscopic third ventriculostomy versus ventriculo-peritoneal shunt). Childs Nerv Syst 2017 Jul;33(7):1157-1168.

41. Tulipan N, Wellons JC 3rd, Thom EA, Gupta N, Sutton LN, Burrows PK, Farmer D, Walsh W, Johnson MP, Rand L, et al. Prenatal surgery for myelomeningocele and the need for cerebrospinal fluid shunt placement. J Neurosurg Pediatr 2015 Dec;16(6):613-620.

42. Brock JW 3rd, Carr MC, Adzick NS, Burrows PK, Thomas JC, Thom EA, Howell LJ, Farrell JA, Dabrowiak ME, Farmer DL, et al. Bladder function after fetal surgery for myelomeningocele. Pediatrics 2015 Oct;136(4):e906-e913. 
43. Carr MC. Urological results after fetal myelomeningocele repair in pre-MOMS trial patients at the Children's Hospital of Philadelphia. Fetal Diagn Ther 2015;37(3):211-218.

44. Horst M, Mazzone L, Schraner T, Bodmer C, Möhrlen U, Meuli M, Gobet R. Prenatal myelomeningocele repair: do bladders better? Neurourol Urodyn 2017 Aug;36(6):1651-1658

45. Clayton DB, Tanaka ST, Trusler L, Thomas JC, Pope JC 4th, Adams MC, Brock JW 3rd. Long-term urological impact of fetal myelomeningocele closure. J Urol 2011 Oct;186(Suppl 4): 1581-1585.

46. Macedo A Jr, Leal M, Rondon A, Ortiz V, Moron AF, Cavalheiro S. Urological evaluation of patients that had undergone in utero myelomeningocele closure: a prospective assessment at first presentation and early follow-up. Do their bladder benefit from it? Neurourol Urodyn 2015 Jun;34(5):461-464.

47. Leal da Cruz M, Liguori R, Garrone G, Leslie B, Ottoni SL, Carvalheiro S, Moron AF, Ortiz V, Macedo A Jr. Categorization of bladder dynamics and treatment after fetal myelomeningocele repair: first 50 cases prospectively assessed. J Urol 2015 May;193(5 Suppl):1808-1811.

48. Johnson MP, Bennett KA, Rand L, Burrows PK, Thom EA, Howell LJ, Farrell JA, Dabrowiak ME, Brock JW 3rd, Farmer DL, et al. The Management of Myelomeningocele Study: obstetrical outcomes and risk factors for obstetrical complications following prenatal surgery. Am J Obstet Gynecol 2016 Dec;215(6):778.e1-778.e9.

49. Antiel RM, Adzick NS, Thom EA, Burrows PK, Farmer DL, Brock JW 3rd, Howell LJ, Farrell JA, Houtrow AJ, Management of Myelomeningocele Study Investigators. Impact on family and parental stress of prenatal vs postnatal repair of myelomeningocele. Am J Obstet Gynecol 2016 Oct;215(4): 522.e1-522.e6.

50. Egloff A, Bulas D. Magnetic resonance imaging evaluation of fetal neural tube defects. Semin Ultrasound CT MR 2015 Dec,36(6):487-500.

51. Righini A, Parazzini C, Doneda C, Arrigoni F, Rustico M, Re TJ, Triulzi F. Fetal MRI features related to the Chiari malformations. Neurol Sci 2011 Dec;32 (Suppl 3):S279-S281.

52. Carreras E, Maroto A, Illescas T, Meléndez M, Arévalo S, Peiró JL, García-Fontecha CG, Belfort M, Cuxart A. Prenatal ultrasound evaluation of segmental level of neurological lesion in fetuses with myelomeningocele: development of a new technique. Ultrasound Obstet Gynecol 2016 Feb;47(2):162-167.

53. Moise KJ Jr, Moldenhauer JS, Bennett KA, Goodnight W, Luks FI, Emery SP, Tsao K, Moon-Grady AJ, Moore RC, Treadwell MC, et al. Current selection criteria and perioperative therapy used for fetal myelomeningocele surgery. Obstet Gynecol 2016 Mar;127(3):593-597.

54. Soni S, Moldenhauer JS, Spinner SS, Rendon N, Khalek N, Martinez-Poyer J, Johnson MP, Adzick NS. Chorioamniotic membrane separation and preterm premature rupture of membranes complicating in utero myelomeningocele repair. Am J Obstet Gynecol 2016 May;214(5):647.e1-647.e7.

55. Meuli M, Meuli-Simmen C, Flake AW, Zimmermann R, Ochsenbein N, Scheer I, Mazzone L, Moehrlen U. Premiere use of Integra artificial skin to close an extensive fetal skin defect during open in utero repair of myelomeningocele. Pediatr Surg Int 2013 Dec;29(12):1321-1326.

56. Meuli M, Meuli-Simmen C, Mazzone L, Tharakan SJ, Zimmermann R, Ochsenbein N, Moehrlen U. In utero plastic surgery in Zurich: successful use of distally pedicled random pattern transposition flaps for definitive skin closure during open fetal spina bifida repair. Fetal Diagn Ther (in press).
57. Zaretsky MV, Liechty KW, Galan HL, Behrendt NJ, Reeves S, Marwan AI, Wilkinson C, Handler M, Lagueux M, Crombleholme TM. Modified hysterotomy closure technique for open fetal surgery. Fetal Diagn Ther 2017 Sep 6. doi: $10.1159 / 000479683$.

58. Bennett KA, Carroll MA, Shannon CN, Braun SA, DabrowiakME,CrumAK,PaschallRL,Kavanaugh-McHughAL, Wellons JC 3rd, Tulipan NB. Reducing perinatal complications and preterm delivery for patients undergoing in utero closure of fetal myelomeningocele: further modifications to the multidisciplinary surgical technique. J Neurosurg Pediatr 2014 Jul;14(1):108-114.

59. Rethmann C, Scheer I, Meuli M, Mazzone L, Moehrlen U, Kellenberger CJ. Evolution of posterior fossa and brain morphology after in utero repair of open neural tube defects assessed by MRI. Eur Radiol 2017 May 12. doi: 10.1007/ s00330-017-4807-y.

60. Ochsenbein-Kölble N, Krähenmann F, Hüsler M, Meuli M, Moehrlen U, Mazzone L, Biro P, Zimmermann R. Tocolysis for in utero surgery: atosiban performs distinctly better than magnesium sulfate. Fetal Diagn Ther 2017 Aug 17. doi: 10.1159/000478261.

61. Bruner JP, Richards WO, Tulipan NB, Arney TL. Endoscopic coverage of fetal myelomeningocele in utero. Am J Obstet Gynecol 1999 Jan;180(1 Pt 1):153-158.

62. Kohl T, Tchatcheva K, Merz W, Wartenberg HC, Heep A, Müller A, Franz A, Stressig R, Willinek W, Gembruch U. Percutaneous fetoscopic patch closure of human spina bifida aperta: advances in fetal surgical techniques may obviate the need for early postnatal neurosurgical intervention. Surg Endosc 2009 Apr;23(4):890-895.

63. Belfort MA, Whitehead WE, Shamshirsaz AA, Bateni ZH, Olutoye OO, Olutoye OA, Mann DG, Espinoza J, Williams E, Lee TC, et al. Fetoscopic open neural tube defect repair: development and refinement of a two-port, carbon dioxide insufflation technique. Obstet Gynecol 2017 Apr;129(4):734-743.

64. Pedreira DA, Zanon N, Nishikuni K, Moreira de Sá RA, Acacio GL, Chmait RH, Kontopoulos EV, Quintero RA. Endoscopic surgery for the antenatal treatment of myelomeningocele: the CECAM trial. Am J Obstet Gynecol 2016 Jan;214(1):111.e1-111.e11.

65. Farmer DL, von Koch CS, Peacock WJ, Danielpour M, Gupta N, Lee H, Harrison MR. In utero repair of myelomeningocele: experimental pathophysiology, initial clinical experience, and outcomes. Arch Surg 2003 Aug;138(8):872-878.

66. Bruner JP, Tulipan NB, Richards WO, Walsh WF, Boehm FH, Vrabcak EK. In utero repair of myelomeningocele: a comparison of endoscopy and hysterotomy. Fetal Diagn Ther 2000 Mar-Apr;15(2):83-88.

67. Shurtleff D. Fetal endoscopic myelomeningocele repair. Dev Med Child Neurol 2012 Jan;54(1):4-5.

68. Mazzone L, Meuli M. Re: Fetoscopic repair of spina bifida: safer and better? Ultrasound Obstet Gynecol 2016 Dec;48(6):802.

69. Flake A. Percutaneous minimal-access fetoscopic surgery for myelomeningocele - not so minimal! Ultrasound Obstet Gynecol 2014 Nov;44(5):499-500.

70. Moise KJ Jr, Flake A. Fetoscopic open neural tube defect repair: development and refinement of a two-port, carbon dioxide insufflation technique. Obstet Gynecol 2017 Sep;130(3):648.

71. Cohen AR, Couto J, Cummings JJ, Johnson A, Joseph G, Kaufman BA, Litman RS, Menard MK, Moldenhauer JS, Pringle KC, et al. Position statement on fetal myelomeningocele repair. Am J Obstet Gynecol 2014 Feb;210(2):107-111. 